\title{
Problem solving in phase diagram of engineering material subject through animation as learning media
}

\author{
Mumu Komaro $^{1 *}$, Ariyano Ariyano ${ }^{1}$, Suherman $\mathrm{A}^{1}$, and Geovani $G \mathrm{~F}^{1}$ \\ ${ }^{1}$ Universitas Pendidikan Indonesia, Jl. Dr. Setiabudhi No. 229, Bandung, Indonesia
}

\begin{abstract}
A preliminary research related to students' difficulties investigated that abstract atomic motion and counting material are the hardest materials to understand by the students. Therefore, to overcome this, a study on multimedia used in material of phase diagram was conducted. The research design was a quasiexperimental method done with pre-test and post-test to collect the data. The results revealed that the use of animation helped students to understand the material and supported them in doing their learning activity well.
\end{abstract}

\section{Background}

Among the students' difficulties in understanding phase diagram material, identifying characteristics of the material is considered one of the problems faced by the students. To master this subject, the students are required to have a specific thinking ability referring to problem solving skill. Problem solving is an ability of giving reasons and reflective thinking [1]. Problem solving is a strategic and active interpretation and evaluation of observation and communication, information and argumentation. This ability is classified into six aspects namely: focus, reason, conclusion, situation, clarity, and review [2]. Therefore, people with problem-solving skill are able to comprehend what they are learning and explain it by using their own words. In addition, problem solving also deals with an ability to explain what is thought, that is learning how to ask, when to ask and what the question is about.

Given the importance of the subjects of Materials Engineering and based on the data showing that students have difficulty in the material phase diagram so that it is necessary to do an effort in improving the learning process. One effort that can be done is using instructional media which is not only in the theoretical level, but it is also practical, economical, accessible (teachable) medium. By doing so, it enables the materials to be learned repeatedly. Animation as the learning media is intended to present learning material more practical, economical, accessible, and teachable, it is done by manipulating theoretical model (picture) into a realistic model in the form of multimedia animation (MMA). This is due to some manipulative features that are able to change theoretical model into a realistic model (animation) which can attract the students' attention to enjoy their learning process and help to understand the materials.
Mastering phase diagram material in engineering subject is commonly considered as a difficult course. In order to make the lecturer easier to teach this subject animation is necessarily implemented although the lecturers need some trainings. By doing so, the teachers will be more familiar with this technology and they understand ways to implement it in learning activity. Therefore, there is no reason for the lecturers not to use e-learning, virtual reality, and interactive multimedia (MMI) in their teaching for their advantages.

So far, studies on the utilization of interactive multimedia (MMI) have proved the advantages of using MMI to improve the quality of learning. For example, Interactive multimedia-based learning has also been implemented and considered as an effective media to the students' achievement particularly problem solving skills of elementary school students [3]. It also improves the ability to read the image projection of vocational school students [4], and learning achievement of assembly and brake system assembly for vocational school students [5].

Moreover, multimedia animation in engineering materials has been applied by Callister [6], although it still limited points of animation such as: 1) the crystal structure in the form of unit cell which does not contain the characteristics of each unit cell determining the mechanical properties of the material; 2) the field and the direction of the crystal which do not yet contain the Phase Diagram determining the ease of the material being formed, or determining the softness and hardness of the material [6].

Based on the explanation above, this study is generally aimed at creating a learning media particularly to determine the improvement of problem-solving skills in the engineering material subject through implementing multimedia animation (MMA) for the students of mechanical engineering education study program.

\footnotetext{
"Corresponding author: $\underline{\text { mumu@,upi.edu }}$
} 


\section{Research methods}

The method of this research is a quasi-experimental design in the form of Non-equivalent Control Group Design. The underlying reason of choosing this design is due to the process of sample selection which is not random. Besides, this choice is based on some difficulty in obtaining a control group which function as controlling the affects of the experiment [7]. The pattern of design in this study can be seen as follows.

Table 1. Non-equivalent Control Group Design.

\begin{tabular}{|c|c|c|c|}
\hline Group & Pre-test & Treatment & Post-test \\
\hline Experiment & TE1 & $\mathrm{X}$ & TE2 \\
\hline Control & TK1 & Y & TK2 \\
\hline
\end{tabular}

Notes:

TE1/TK1 = pre-test given to the students

$\mathrm{X}=\mathrm{E}-\mathrm{MMA}$ as learning media

$\mathrm{Y}=$ pictures and hand-out as learning media

TE2/TK2 = post-test given to the students

Average scores of the two groups are used to see differences of $\mathrm{N}$ gain between the experimental and control group. According to Hake [8], the calculation can be seen as follow:

$$
\begin{aligned}
(N-\text { Gain }) & =\frac{\% \text { actual gain }}{\% \text { potential gain }} \\
& =\frac{\% \text { post test score }-\% \text { pretest score }}{100-\% \text { pretest score }}
\end{aligned}
$$

In this study, $\mathrm{N}$-gain descriptive analysis is also implemented by using $\mathrm{N}$-gain criteria according to Hake [8] which means that: the improvement in high category, if $(\mathrm{N}$-gain) $>0,7$; the improvement in middle category if $0,7 \geq(N-$ Gain $) \geq 0,3$; and the improvement in low category, if $(N-$ Gain $)<0,3$.

\section{Findings and discussions}

The findings of preliminary study show that the students who take the engineering material subject have some difficulties in mastering an abstract matter and atomic motion. Therefore, it is necessary to do an effort to improve the process of learning which can ease students to understand the materials. Implementing MMI is one innovative media which is a practical, economical, accessible (teachable) medium enable to understand the learning materials since it can be learned repeatedly. Consequently, this media meets accessible criteria that can be pursued by manipulating theoretical model (picture) into a realistic model. This learning media can be seen in the following figure 1, and figure 2 .

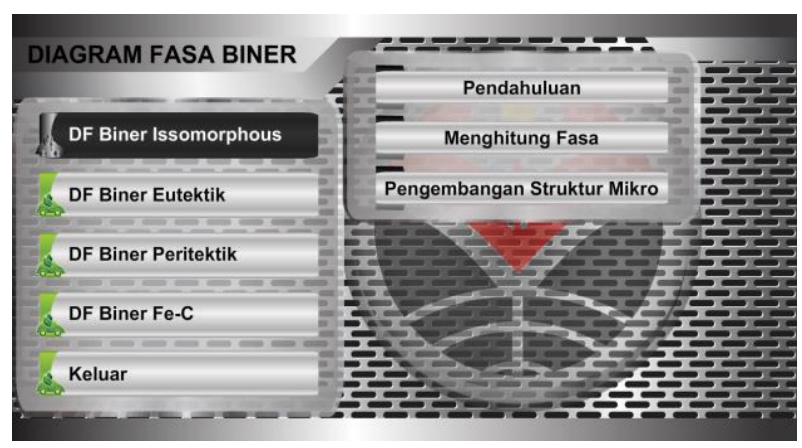

Fig. 1. Menu of FD Biner Issomorphous.

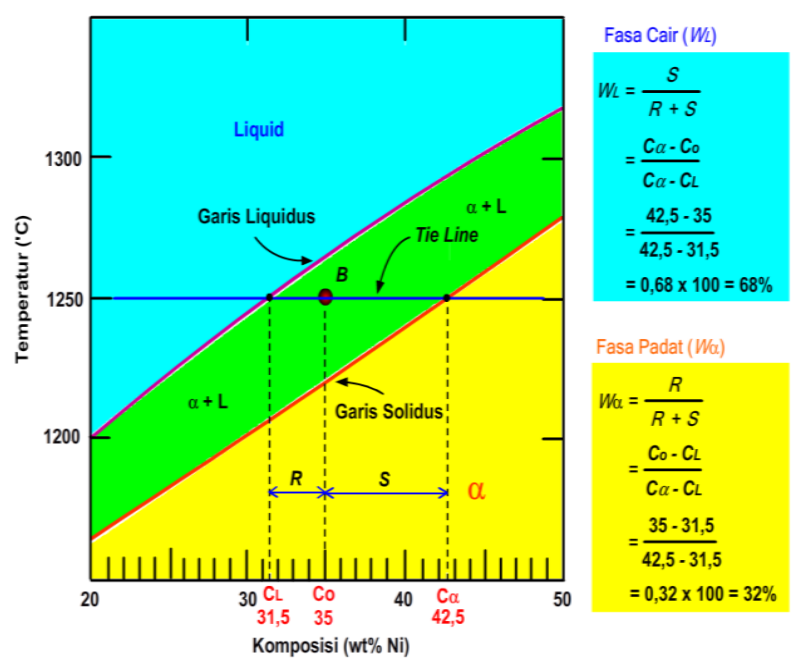

Fig. 2. Material of Phase Diagram Biner Issomorphous.

Multimedia animation phase diagrams are created as representative instructional media to explain the concept of a system clearly which provide the students to get experience in their learning [9]. To collect the data, this study applied pre-test and post- test to either control class or experimental class. The obtained data were used to calculate the N-Gain value to see the improvement of the students' ability. The N-Gain values are presented in Table 2.

Table 2. The results of Pre-Test, Post-Test, and N-Gain Problem solving in Phase Diagram.

\begin{tabular}{|l|c|c|}
\hline Average Score & Control & Experiment \\
\hline Pre Test & 0.82 & 4.05 \\
\hline Post Test & 66.12 & 86.57 \\
\hline N-Gain (\%) & 65.91 & 85.80 \\
\hline
\end{tabular}

The above table 2 demonstrates that students' problem solving ability in phase diagram materials using MMA tend to be improved with an average score of $85.80 \%$ indicating it is in high category. Even form the calculation result, it shows higher improvement of problem-solving ability than using pictures as media which increases to an average score of $65.91 \%$ or reaches a moderate category.

In addition, MMA also provides advantages to teach science subjects and it helps students understand learning materials more easily [10]. However, educational experts create different educational media with different emphases according to their media type, as 
well as the principles used for multimedia: multimedia, spatial closeness, temporal proximity, coherence, modality, redundancy, and individual differences [11].

Regarding special principles that characterize the multimedia animation phase diagram is accessible, and affordable, if the learners provide their reasons appropriately. This strategy is considered as the main emphasis associated with the characteristics of the Engineering Materials course that are characterized by their micron properties, namely: atomic structure, and dynamic, and abstract atomic motions. As a result, a very small and abstract size of micro-structure, requires appropriate media to understand it, and for that MMA is a medium that can meet these needs.

MMA engineering material is intended to create the students' centered media which involve learners in the simulation of thought, so that the learning outcomes increase as a result of students' involvement in the simulation [12]. The basic principles of making MMA produce better learning outcomes and imprints. The Better results also explained that there was a relationship between the media in the form of live images or animation to the learning outcomes [13]. This is even proved that this media is not only increased $10 \%$ performance but it is upgraded to $60 \%$ with multimedia [14]. The multimedia is a combination between readable text, audible sounds, images and motion or animated views. The students can obtain an in-depth comprehension material since they use their long-term memory (Long-term Memory) as reported by Mayer [10], and Berk [15].

\section{Conclusions}

Based on the findings and discussions above, it can be concluded that MMA as instructional media can improve the students' problem solving ability in phase diagram materials in a high category. This result is higher than the improvement of problem solving ability through using other instructional media such as image and handout that achieve a middle category. In other words, MMA phase diagram is proved to be an innovative media that can improve the students' problem solving skill into the high level. This is due to the role of the media to ease the students to understand their learning material and it facilitates them in doing their learning activity.

\section{References}

1. Fisher, A. An introduction to problem solving, (Erlangga, Jakarta, 2009)

2. Azizah. Peningkatan Pemecahan masalah Matematis Siswa Melalui Penerapan Pendekatan Open Ended. (Penelitian Tindakan Kelas. UIN, 2014).

3. Masitoh, T. Efektivitas Pembelajaran IPA Kelas Tinggi Berbasis Multimedia Interaktif untuk Meningkatkan Keterampilan Pemecahan masalah
Mahasiswa Calon Guru SD. Seminar Nasional Pendidikan MIPA, Unila. (2011)

4. Anam C. Khumaedi M. dan Basyirun. Pembelajaran Ceramah dengan Media Animasi untuk Mengingkatkan Kemampuan Siswa Dalam Membaca Gambar Proyeksi, J Pend Tek Mesin, Volume 9, No. 1, Juni 2009: 7 - 13 (1) (2009)

5. Harsono B. Soesanto dan Samsudi. Perbedaan Hasil Belajar antara Metoda Ceramah Konvensional dengan Ceramah Berbantuan Media Animasi pada Pembelajaran Kompetensi Perakitan dan Pemasangan Sistem Rem. J. Pend. Tek. Mesin, Volume 9, No. 2, December 2009: 71 - 79 (2) (2009)

6. Callister, W. D Jr., Material Science And Engineering, An Introduction, (Salt Lake City, Utah, 2004)

7. Sugiyono. Metode Penelitian Pendidikan Pendekatan Kuantitatif, Kualitatif, dan $R \& D$. (Alfabeta, Bandung, 2014)

8. Hake, R R. Relationship of Individual Student Normalized Learning Gains in Mechanics with Gender, High-School Physics, and Pretest Scores on Mathematics and Spatial Visualization. The Physics Education Research Conference; Boise, Idaho (2002)

9. Purnawan. Desain Model Komponen Pneumatik untuk Media Pembelajaran Mekanisme Komponen Pneumatik, J INVOTEC, Volume III, No. 9, August 2006 : 116 - 124. (2006)

10. Mayer, R.E. Applying the science of learning: evidence-based principles for the design of multimedia instruction. The American psychologist, 63(8), pp.760-769. (2008)

11. Mayer, R. Mayer. Principles of Multimedia Design. Multimedia Learning. pp. 5-10. (2001)

12. Fadel C. Multimodal Learning Through Media: What the Research Says. (2008).

13. Munadi Y. A new approach of learning media (Media Pembelajaran (Sebuah Pendekatan Baru). (Referensi, Jakarta, 2013)

14. Munir. Information and communication technology-based curriculum (Kurikulum Berbasis Teknologi Informasi dan komunikasi). (Alfabetha, Bandung, 2010)

15. Berk, R. A. Multimedia teaching with video clips: $\mathrm{TV}$, movies, YouTube, and $\mathrm{mtvU}$ in the college classroom. Int. J. of Technology in Teaching and Learning. Volume 5, No.1. Pp. 1-21. (2009) 